\title{
O Euclides e Seus Rivais Modernos, de Lewis Carroll (1879): uma apresentação
}

\author{
Euclid and His Modern Rivals, by Lewis Carroll (1879): A \\ Presentation
}

\author{
Rafael Montoito* \\ Antonio Vicente Marafioti Garnica**
}

\begin{abstract}
Resumo
A intenção deste artigo é apresentar para o leitor brasileiro o livro Euclides e Seus Rivais Modernos, de Lewis Carroll, publicado em 1879 e recentemente traduzido para o português. A apresentação se inicia com a discussão sobre qual edição d'Os Elementos, de Euclides, Carroll usou como guia de referência para compor seu texto, do que seguem algumas considerações sobre o estilo teatral usado por ele para compor esta obra, julgando que talvez essa opção manifeste, também neste caso, a influência shakespeareana percebida em outros de seus textos. A apresentação proposta pelo artigo termina com uma discussão resumida do corpus do livro.

Palavras-chave: Euclides e Seus Rivais Modernos. Lewis Carroll. Exame Hermenêutico. Teatro. Geometria.

Abstract

The main intention of this paper is to present the book Euclid and His Modern Rivals, by Lewis Carroll, published in 1879 and recently translated to Portuguese, to the Brazilian reader. Such presentation starts with some brief remarks on the edition of The Elements, which Carroll took as his original guide, and continues with some considerations about Carroll's option in using a theatrical style based on Shakespearean plays. In order to finish this presentation, this paper brings a discussion of the corpus of the book, summarizing its content.
\end{abstract}

Keywords: Euclid and His Modern Rivals. Lewis Carroll. Hermeneutical Approach. Theater. Geometry. Book's Review.

\footnotetext{
* Doutor em Ensino de Ciências pelo Programa de Pós-Graduação em Educação para a Ciência da Universidade Estadual Paulista (UNESP), Bauru, São Paulo, Brasil, . Docente do Instituto Federal SulRio-Grandense (IFSUL), Coordenadoria de Matemática (CINAT - Matemática), inserir o nome da cidade, Rio Grande do Sul, Brasil, Endereço para contato: Rua Baldomero Trápaga, 100, Bairro Nossa Senhora de Fátima, CEP 96075-540, Pelotas - RS, Brasil. E-mail: xmontoito@ig.com.br

** Doutor em Educação Matemática pelo Programa de Pós-graduação em Educação Matemática da UNESP de Rio Claro. Docente da Faculdade de Ciências da Universidade Estadual Paulista (UNESP), Bauru, São Paulo, Brasil, e dos Programas de Pós-Graduação em Educação para a Ciência da Universidade Estadual Paulista (UNESP), Bauru, São Paulo, Brasil, e Educação Matemática da Universidade Estadual Paulista (UNESP), Rio Claro, São Paulo, Brasil. Endereço para contato: Departamento de Matemática - Avenida Luiz Edmundo C. Coube, s/n, CEP 17033-360, Bauru-SP, Brasil.E-mail: vgarnica@fc.unesp.br.
} 


\section{Notas iniciais}

O percurso que resultou neste artigo iniciou-se com um projeto de pesquisa cujo objetivo central era a tradução do texto Euclid and His Modern Rivals, de Charles L. Dodgson (Lewis Carroll), publicado pela MacMillan em 1879, da qual decorreria um exame hermenêutico desta obra, pautado principalmente nos trabalhos de John Thompson e Gérard Genette ${ }^{1}$. Em síntese, o livro de Carroll defende a permanência, nas escolas inglesas, d'Os Elementos, de Euclides, como a única obra de referência para o ensino de Geometria, numa época em que, atendendo a uma conjuntura bastante complexa, várias iniciativas de alteração nos currículos e programas escolares defendiam a necessidade de haver outros materiais para o ensino. Como decorrência desse estado de coisas da época vitoriana, vários manuais para o ensino de Geometria começaram a ser elaborados e publicados e uma miríade de discussões entre autores, associações e matemáticos passou a ocupar os eventos e as páginas dos jornais. Defendendo o livro de Euclides dos ataques, Carroll elabora o Euclides e Seus Rivais Modernos como uma peça de teatro na qual um professor, Minos $^{2}$, cansado do trabalho árduo de corrigir exames, recebe, em sonho, a visita de um Euclides fantasmagórico com a proposta de, em dupla, procederem a uma análise minuciosa de boa parte dos manuais então recentemente produzidos visando a avaliar se há, dentre esses livros, algum mais adequado que Os Elementos. A situação surreal permite que o leitor acompanhe Minos e Euclides julgando as obras de Legendre, Cooley, Cuthbertson, Henrici, Wilson, Pierce, Willock, Chauvenet, Loomis, Morell, Reynolds, Wright, o Programa da Associação para a Melhoria do Ensino de Geometria (AIGT) e o

\footnotetext{
${ }^{1}$ Trata-se dos pressupostos que fundamentam o que conhecemos hoje por Hermenêutica de Profundidade (HP), radicados principalmente nos trabalhos de John Thompson, sociólogo inglês assumidamente influenciado por Paul Ricoeur, em sua obra Ideologia e Cultura Moderna: Teoria social crítica na era dos meios de comunicação de massa (THOMPSON, 1995) e por alguns (ainda poucos) pesquisadores brasileiros na área de Educação Matemática. De Gérard Genette (GENETTE, 2009) vem o conceito de paratexto, que apoia significativamente a HP quando o objeto de análise é um texto escrito.

${ }^{2}$ Minos e Rhadamanthus (ou Rhadamanthys ou Rhadamanthos) - personagens que, com o fantasma de Euclides, frequentam as duas primeiras cenas do primeiro ato de Euclides e Seus Rivais Modernos - são nomes de dois dos três juízes infernais, que atuam sob o poder de Hades. Assim na obra de Carroll, ambas as personagens julgam estudantes e autores de manuais rivais ao de Euclides - o que Carroll sugere ser uma tarefa infernal, a julgar pelo nome dos protagonistas - na mitologia grega Rhadamanthus, Minos e Eacos julgavam as almas que chegavam ao Inferno. Minos segue como personagem, dialogando com Euclides, até o final da obra.
} 
Programa-Manual de Wilson. Com isso, sutilmente, o leitor percorre os caminhos do pensamento matemático da época, principalmente quanto aos modos como esses autores propunham sua sistematização para a Geometria. Defensor de Euclides, Carroll alinha a trama de modo a concluir que todos os livros trazem, em algum momento ou de algum modo, paradoxos, lacunas, incorreções ou atualizações inúteis.

Neste artigo pretendemos apresentar algumas das várias faces desse exame hermenêutico feito a partir da tradução de Euclides e Seus Rivais Modernos, dadas as limitações quanto à quantidade de laudas. Assim, este texto é parte de uma série de textos cujo conjunto é a hermenêutica - parcial, inacabada, como ocorre a qualquer movimento de interpretação - inicialmente pretendida.

\section{O Euclides de Carroll}

Uma das questões surgidas no processo de tradução e análise de Euclides e Seus Rivais Modernos foi sobre a edição d'Os Elementos que Carroll tão amiúde consultava. A melhor edição de Euclides, na opinião de Carroll (WILSON, 2009), era a publicada pela Robert Potts, intitulada The School Edition, Euclid's Elements of Geometry, the first six books, chiefly from the text of Dr. Simson, with Explanatory Notes ${ }^{3}$. A edição de Simson foi traduzida para a língua inglesa a partir da tradução latina de Frederico Commandino que, por sua vez, era a tradução da edição em grego de Théon. Tem-se aí um pequeno problema: a edição de Théon - contaminada pelas inserções de Théon, que julgou necessário fazer algumas alterações na obra original - tem certas diferenças com relação à original, como a que ocorre quanto ao uso do termo axioma ao invés de noções comuns, ou aquela relativa à redução do número de postulados (para três ao invés de cinco) ou ao aumento na quantidade de definições (na edição de Théon há vinte e cinco, ao invés de vinte e três), e as alterações quanto à numeração das proposições e estas diferenças podem ser notadas em diversos trechos de Euclides e Seus Rivais Modernos (Carroll, por exemplo, cita o axioma 12 e os corolários 1 e 2, relativos à

\footnotetext{
${ }^{3}$ Publicada em 1845, esta edição ainda se encontra à venda. Ela é baseada na primeira edição de Simson para a língua inglesa (The Elements of Euclid, viz. the First Six Book Together with the Eleventh and Twelfth), publicada em 1756, na qual ele afirma ter corrigido alguns erros que Théon e outros tradutores cometeram ao longo dos séculos, restaurando assim algumas demonstrações de Euclides (HEATH, 1956). Também é possível encontrar em circulação a tradução portuguesa Elementos de Euclides dos Seis Primeiros Livros, do Undécimo e Duodécimo, da Versão Latina de Frederico Commandino, impresso pela Universidade de Coimbra. A edição dessa tradução que temos em mãos - parte do acervo do GHOEM - é a de 1855.
} 
proposição 32 , que inexistem no original grego $)^{4}$, o que leva a crer que a edição-mãe que Carroll tinha à mão provinha daquela organizada por Théon.

Carroll, que apreciava e se dedicava tanto à geometria, também gostava e conhecia bem o grego - um par perfeito para se identificar com Euclides e pretender decifrá-lo -, uma vez que estudou na Richmond ${ }^{5}$ Grammar School $^{6}$ entre 1844 e 1845 e que, segundo seus biógrafos, era bastante dedicado aos estudos. Em 1851, Carroll passou a integrar a comunidade estudantil da Christ Church, na Universidade de Oxford, onde seu pai estudara. Para ingressar nela, prestava-se um exame de admissão em que pesavam os conhecimentos de latim e grego (CHASTENET, [s/d]). Carroll obteve nota alta no Responsions, a primeira prova para a obtenção do grau de bacharel, que incluía uma arguição oral, uma monografia de latim, grego e aritmética, com opção entre álgebra e geometria euclidiana (COHEN, 1998). Com o tempo, seu conhecimento de grego e latim deve ter atingido um patamar de excelência que lhe permitiu, em 1854, declamar no hall da universidade um texto que havia escrito inteiramente em latim e grego e cuja trama se desenvolvia em torno de uma passagem da Ética de Aristóteles ${ }^{7}$ (COHEN, 1998). Seus estudos seguiram tão bem que ele recebeu vários prêmios e, em 1854, colou grau de Bacharel em Artes (B.A.), tornando-se professor de Oxford com apenas 23 anos.

No ensino de geometria, Carroll mostrou-se devotado a Euclides. Tal devoção evidencia-se pela quantidade de escritos por ele publicados sobre geometria euclidiana. Seu primeiro folheto foi Notes on the First Two Books of Euclids (1860), vendido a seis pence $^{8}$ e destinado àqueles que deveriam submeter-se aos exames elementares. As Notes de Carroll cresceram até adquirir forma de livro, o Euclid, Books I, II, do qual circulou

\footnotetext{
${ }^{4}$ Para o cotejamento entre as edições consideramos a edição original da tradução de Simson para o português, a tradução direta do grego para o português (elaborada por Irineu Bicudo e publicada pela Editora da UNESP) e, é claro, as indicações do próprio original do Euclid and His Modern Rivals, de Carroll, em duas de suas edições originais, reimpressas sob demanda.

${ }^{5}$ A Richmond Grammar School era do tipo internato quando Carroll estudou lá (COHEN, 1998).

${ }^{6}$ A grammar school é um dos tipos de escola da Inglaterra que, na Idade Média, tinha por objetivo o ensino do latim. Posteriormente, foram incluídos no seu currículo o grego antigo e outras línguas europeias, além de ciências naturais, matemática, história, geografia, entre outros assuntos. Na época vitoriana, as grammar schools foram reorganizadas para dedicar-se à educação secundária do Reino Unido, com exceção da Escócia, que seguia outra organização (COHEN, 1998).

${ }^{7}$ Carroll inspirava-se em Platão e Aristóteles e, mais tarde, dedicaria sua obra Symbolic Logic, Part I à memória de Aristóteles. No entanto, ainda que elogiasse o filósofo ocasionalmente, seus estudos eram fortemente criticados por Carroll. No mesmo Symbolic Logic, Part I, o autor escreveu que "o método lógico de Aristóteles constitui um mecanismo quase inútil, em termos práticos, sendo muitas das conclusões incompletas e ignoradas várias formas perfeitamente legítimas" (CARROLL apud COHEN, 1998, p. 70).

${ }^{8}$ Pence é o plural de penny, a menor unidade da moeda britânica: um centavo de libra.
} 
uma versão em forma de anotações desde 1875 até sua publicação como livro em 1882. Euclid, Books I, II atingiu a marca de oito edições (WILSON, 2009).

Seguiram-se outras obras que deixam clara a preocupação de Carroll com o ensino de Geometria. Ele reescreveu e aperfeiçoou um dos livros de Euclides, ao qual chamou de The Fifth Book of Euclid Treated Algebraically, recorrendo a exemplos para ilustrar cada definição e formulando cada proposição de modo algébrico por julgar essa forma mais acessível. Visando a simplificar os textos, desprezou a teoria das magnitudes incomensuráveis, que considerava desnecessária para o seu público alvo (WILSON, 2009) e mesmo sabendo que os livros de Euclides eram conhecidos e estudados, apresentou sobre eles vários estudos novos, atingindo a marca de quatorze textos publicados entre 1860 e 1888 (dentre os quais estão A Syllabus of Plane Algebrical Geometry, Notes on the First Two Books of Euclid Designed for Candidates for Responsions, Curiosa Mathematica - Part I: A New Theory of Parallels, que são tentativas de tornar os dois primeiros livros de Euclides acessíveis aos alunos de graduação e a outros estudantes). Mas talvez Euclides e Seus Rivais Modernos seja o livro que representa mais claramente uma cruzada pessoal do autor: os textos acima citados preocupavam-se mais em facilitar a aprendizagem da geometria euclidiana, enquanto que este livro, especificamente, tinha por objetivo defender o uso da obra de Euclides para o ensino da geometria (uma defesa, na verdade, da memória de Euclides, como expresso já na dedicatória do livro ${ }^{9}$ ).

\title{
Voltemos a Os Elementos:
}

\begin{abstract}
Uma das características de Os Elementos a que não tivemos que nos referir até agora é a conduta lógica formal da exposição, que lembra a teoria aristotélica do silogismo: divisão sistemática por proposições. Em cada proposição, primeiro a enunciação de uma tese em termos gerais, logo nova enunciação aplicada a uma figura particular. Finalmente, uma demonstração sobre a figura. A demonstração dividida em uma série de conclusões particulares em cadeia e terminando regularmente com a afirmação 'como queríamos demonstrar'. É bem possível que tal formalismo imitasse de perto algo da dialética sofística e não é nem um pouco absurdo pensar que essa forma fosse adotada por um discípulo de Sócrates, o fustigador de seus contemporâneos sofistas, pois o que Sócrates combate não é a forma, que até certo ponto ele também conserva em suas análises dialogadas, e sim o erro que se esconde em deduzir, por raciocínios formalmente exatos, a partir de premissas variáveis e enganosas (LEVI, 2008, p. 84-85).
\end{abstract}

\footnotetext{
${ }^{9}$ Dedicado à memória de Euclides
} 
É possível imaginar que Carroll também reverenciasse a obra de Euclides no que tange à sua organização lógica ${ }^{10}$, pois não pode ser coincidência o fato de a maioria dos escritos sérios de Carroll sobre matemática versarem sobre geometria euclidiana e lógica matemática. Ele mesmo afirma, em suas publicações sobre os livros de Euclides, que seu objetivo era trazer à tona o que implicava o método euclidiano, sem a verborragia e redundâncias vinculadas a ele com o passar dos anos. Para cumprir tal intento, Carroll confessa que tomou a liberdade de alterar e abreviar a forma de redizer passagens de Euclides quando isso lhe pareceu oportuno, sem modificar, entretanto, seus métodos de demonstração ou sua sequência lógica (WILSON, 2009).

Carroll também foi um dos que se esforçou para demonstrar o quinto postulado de Euclides. Suas anotações contam como foi o fim deste intento: "Depois de muitas noites acordado, acabei como o duende Puck ${ }^{11}$, 'piscando e fazendo caretas'. Cada vez que pensava que havia conseguido, deparava-me com algum tropeço imprevisto e o espírito burlão 'entre risinhos, punha-se a brincar como um louco' " (CARROLL apud WILSON, 2009, p. 122). Carroll chegou a reescrever o quinto postulado de uma maneira romanceada:

\begin{abstract}
Era uma deliciosa tarde de outono, e os efeitos gloriosos do extravio cromático começavam a se insinuar na atmosfera, enquanto a terra girava afastando-se do grande luminar do oeste, quando duas retas puderam ser vistas dirigindo seu traço tedioso por uma superfície plana. A mais velha das duas parecia ter aprendido, por um exercício prolongado, a arte, tão penosa para alguém jovem e impulsivo, de permanecer a igual distância de ambos os extremos; mas a mais jovem, com a impetuosidade própria de sua tenra idade, estava sempre desejando divergir e transformar-se em hipérbole ou em alguma igualmente romântica e infinita curva. Haviam vivido e amado muito: o destino e as superfícies interjacentes as haviam mantido até agora separadas, mas esta situação estava por mudar: uma reta as havia cruzado, fazendo com que os dois ângulos interiores fossem menores que dois ângulos retos. Foi um instante inesquecível e, enquanto continuavam seu percurso, um sussurro agitou as superfícies em isócronas ondas de som. 'Oh, sim, acabaremos por nos encontrar se formos prolongadas indefinidamente!' (CARROLL, 2002b, p. 169).
\end{abstract}

Outro texto no qual Carroll se vale das ideias euclidianas, elaborando definições e postulados que remetem a Os Elementos, é o publicado em 1865, por ocasião da eleição para o parlamento de Oxford:

Definições

\footnotetext{
${ }^{10}$ Não devemos concluir, por suas publicações e por sua defesa de Euclides, que Carroll desconhecia as geometrias não-euclidianas: segundo Wilson (2009), ele apenas não lhes dava muita atenção porque, em sua opinião, eram irrelevantes para o mundo real.

${ }^{11}$ Personagem de Sonho de Uma Noite de Verão, de Shakespeare.
} 
I) Plena Superficialidade é o caráter de um discurso no qual qualquer um dos dois extremos, escolhidos ao acaso, mostre que o orador mente por completo no que se refere a estes pontos.

II) Plena Divergência é a inclinação de dois votantes, um com relação ao outro, quando, ao se encontrarem, seus pontos de vista não recorrem à mesma direção.

III) Quando um censor, encontrando-se com outro, ao realizar o escrutínio dos votos, encontra quantidades iguais para cada um, o sentimento com que cada parte obsequia a outra chama-se Ira Mediana ou Divergência Ortogonal. IV) Quando duas partes, ao se esbarrarem, experimentam uma Ira Mediana (Divergência Ortogonal), diz-se que cada uma é Complementar da outra (ainda que, falando com propriedade, isso nem sempre esteja certo).

V) Uma cólera obtusa (Divergência Obtusa) é aquela maior que uma Ira Mediana (Divergência Ortogonal).

Postulados

I) Dá-se por suposto que um conferencista pode efetuar divagações de um ponto qualquer a outro.

II) Que um argumento finito (isto é, terminado, acabado) pode alcançar uma extensão qualquer em debates subsequentes.

III) Que se pode promover uma controvérsia de qualquer tema, e a qualquer distância deste tema.

(CARROLL, 2002b, p. 171-173).

\section{O Teatro, Carroll e as cenas de Euclides}

Várias são as questões que devem nortear um exame hermenêutico e dentre elas, certamente, está a preocupação quanto a opção do autor para a escolha do estilo do texto. Isso implica buscar referencias - se houver - que justifiquem, de modo plausível, essa escolha. Euclides e Seus Rivais Modernos foi elaborado como uma peça de teatro. Na biografia de Carroll - na qual podem existir argumentos que dão lastro a essa opção - Cohen (1998), o biógrafo, cita um trecho do diário deste em que ele esclarece que o estilo teatral lhe permitiria tratar assuntos densos com alguma leveza, servindo também para, numa exposição dialogada, expor tanto os argumentos dos rivais quanto os dos defensores de Euclides. A pergunta passa a ser, então: sob que condições e a partir de quais experiências Carroll escreveu Euclides e Seus Rivais Modernos como peça de teatro?

A primeira pista remete à infância de Carroll, quando ele costumava escrever pequenas peças para bonecos para entreter seus irmãos. Outra pista encontramos em livros sobre Carroll (GATTEGNO, 1990; FOULKES, 2005) que tanto afirmam inequivocamente o desejo manifesto do autor de escrever uma edição de Shakespeare 
para meninas quanto aponta sua relação de aprovação ao teatro, contrária, muitas vezes, à opinião dos demais membros da igreja ${ }^{12}$.

A ligação estreita entre Carroll e o teatro de sua época aparece detalhadamente descrita no livro Lewis Carroll and the Victorian Stage: Theatricals in a Quite Life, de Richard Foulkes. Para nós, aqui, interessam apenas as narrativas do autor que parecem, de algum modo, ligar-se à produção de Euclides e Seus Rivais Modernos, mas talvez seja apropriado apresentar uma síntese da relação entre Carroll e o teatro, para que se compreenda que Carroll não era somente um frequentador assíduo, mas alguém que realmente se envolveu com esta forma de arte, muito antes - e continuou bem depois da montagem das aventuras de Alice chegar à cena. Seus diários registram de forma bastante clara essa sua relação com o teatro britânico que, à época, passava por um processo de expansão, rejuvenescimento e diversificação sem precedentes.

As idas ao teatro e as adaptações para o palco das aventuras de Alice ${ }^{13}$ fizeram de Carroll um nome conhecido neste meio. Não era raro Carroll enviar cartas para o St. James's Gazette, o Sunday Times e o The Guildford Gazette Extraordinary, por exemplo, defendendo a presença das crianças nas montagens teatrais o que, por controvérsias da época, queriam abolir. Carroll sublinhou que não havia nenhum mal, aos olhos de Deus, em as crianças atuarem em peças boas, e que o dinheiro que ganhavam era, muitas vezes, fundamental para que suas famílias se mantivessem, dada a pobreza que assolava a maioria delas (COHEN, 1998). No entanto, sugeriu que alguns cuidados fossem tomados: dentre outros, a necessidade de as meninas com menos de dezesseis anos e os meninos com menos de quatorze terem uma licença, anualmente renovável, para atuar, e a garantia de que permaneceriam nas escolas. "Seu interesse nas condições de trabalho dos jovens atores e atrizes e sua sensatez parecem ter influenciado a legislação aprovada em 1889" (FOULKES, 2005, p. 201). Outras cartas, às vezes dirigidas aos produtores, diretores ou atores conhecidos, tinham a intenção de sugerir mudanças na produção ou indicar alguma amiga conhecida para determinado papel (COHEN, 1998).

\footnotetext{
${ }^{12}$ Carroll ordenou-se diácono da igreja anglicana em 1861, com planos de fazer os votos para presbítero como seu pai - posteriormente, o que acabou não acontecendo. Reverendo é o título atribuído tanto aos diáconos quanto aos presbíteros anglicanos (o que difere entre eles são determinadas atividades da igreja que somente os presbíteros podem realizar). É comum encontrar autores que se referem a Carroll como reverendo e outros que se referem a ele como diácono.

${ }^{13}$ Alice no País das Maravilhas e Através do Espelho e o que Alice Encontrou Lá foram montadas, pela primeira vez, em 1879 e 1882, respectivamente. Ambas foram produzidas por Kate Freiligrath-Kroeker.
} 
Desta sua produção, é curioso o artigo enviado por ele para a The Guildford Gazzette Extraordinary, publicado em 29 de dezembro de 1869. Abaixo do título "Abertura do Novo Teatro", aparece "do nosso correspondente especial Sr. Lewis Carroll”, ressaltando o pseudônimo do autor ${ }^{14}$. No corpo do artigo lê-se a citação "Se por acaso falo de maneira um pouco grosseira, perdoem-me"15, de Shakespeare, que abre o longo texto de dezesseis páginas. Carroll escreve sobre a inauguração do teatro, o que ele representa para a população, descreve as instalações, a decoração, as performances etc (FOULKES, 2005).

Uma possível explicação para o fato do pseudônimo de Carroll associar-se à sua personalidade quando o assunto é teatro é oferecida por Gattegno (1990) que vê, nisso, a possibilidade de Carroll experienciar momentos de liberdade e fantasia, diferentemente do que ocorria em seu cotidiano no qual desenvolvia trabalhos mais sérios: a forte influência de seu pai em sua educação parece ter criado nele a ideia de que o teatro era um ambiente vivo para um seu outro eu. O teatro, apontado por Collingwood como um dos motivos que pode ter levado Carroll a não fazer seus votos para presbítero ${ }^{16}$, suscitava no autor fortes emoções.

Por que essas considerações parecem importantes num movimento de exame hermenêutico do livro de Carroll? Porque o livro sobre Euclides - além de representar a maturidade das obras de Carroll sobre geometria euclidiana - é, também, a maturidade de seus escritos em forma de peça de teatro.

A geometria euclidiana e o teatro acompanharam Carroll desde a infância e aparecem, com maior ou menor ênfase, em suas obras: a geometria, sob as orientações de Euclides, e o teatro, em sua grande parte, sob as de Shakespeare ${ }^{17}$. A opção por escrever Euclides e Seus Rivais Modernos em forma de teatro não foi somente impelida pela necessidade dos diálogos ou do humor, mas também porque Carroll deu, desde

\footnotetext{
${ }^{14}$ Lewis Carroll é pseudônimo de Carles Ludwig Dodgson. Com seu nome de batismo, aliás, o autor assina seus trabalhos relacionados à Matemática e, particularmente, o Euclides e Seus Rivais Modernos.

${ }^{15}$ Frase de Henrique VIII, Ato I, Cena IV.

${ }^{16}$ Obviamente não se sabe - nem se poderá saber - por que Carroll não se tornou presbítero. S. D. Collingwood, seu sobrinho e biógrafo, comenta que um dos motivos pode ter sido a estreita ligação de Carroll com o teatro, uma união vista com maus olhos pelo seu pai e por outros membros da congregação. (COHEN, 1998).

${ }^{17}$ No teatro, Carroll viu, de Shakespeare, montagens de As Alegres Comadres de Windsor, Como Gostais,

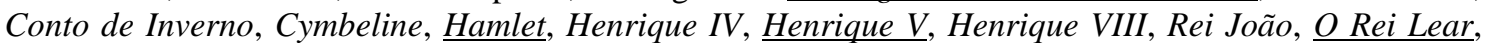
Macbeth, A Megera Domada, O Mercador de Veneza, Muito Barulho por Nada, Noite de Reis, Péricles, Ricardo II, Ricardo III, Romeu e Julieta, Sonho de uma Noite de Verão e A Tempestade (FOULKES, 2005). As peças cujos títulos aparecem aqui sublinhados (inclua-se, entre elas, Antônio e Cleópatra), têm frases citadas por Carroll em Euclides e Seus Rivais Modernos.
} 
muito cedo, vazão às suas emoções e crenças usando como meio textos teatrais - textos estes que, sem dúvida, estão impregnados de nonsense ${ }^{18}$. Já na primeira incursão de Carroll pelo mundo do teatro - o poema intitulado A Quotation from Shakespeare with Slight Improvements, publicado em 1845, que é uma adaptação dos diálogos de Henrique IV, Parte II, em que o autor parodia a cena do rei em seu leito de morte pode-se perceber a mobilização cuidadosa da linguagem e dos múltiplos significados das palavras.

O significado das palavras, para alguns personagens de Carroll (como o Humpty Dumpty de Através do Espelho e o Que Alice Encontrou Lá), é o significado que o próprio personagem lhe infere: isto cria um novo uso para a linguagem, tal como conhecíamos antes, e culminará, em suas obras, nas palavras-mala. As palavras-mala (ou palavras-valise) são palavras criadas por Carroll pela junção de duas ou mais palavras que, ao amalgamarem seu significado, criam outro novo. Esse tipo de neologismo aparece em vários livros de Carroll: discodais, por exemplo, é utilizada em Euclides e Seus Rivais Modernos para referir-se às retas que não têm nenhum ponto em comum (disjuntas) e são codirecionais. As perguntas que o rei faz ao seu filho, em $A$ Quotation from Shakespeare with Slight Improvements, têm por essência o uso e o significado das palavras com as quais seu filho lhe responde. Essas perguntas parecem ecoar, anos à frente, naquelas que são feitas por Minos sobre os livros dos rivais modernos.

Citações literárias, como excerto ou epígrafe, Carroll usa à exaustão em Euclides e Seus Rivais Modernos. Há referências do poeta romano Juvenal, de Horácio, John Milton, Dickens, Percy Bysshe Shelley, Matthew Prior, Lord Byron, Robert Southey, William Wordsworth, John Selden, Samuel Taylor Coleridge... e onze citações de Shakespeare!

\footnotetext{
${ }^{18}$ Não é muito abundante a literatura sobre o nonsense, sua origem, suas características e as suas relações com a obra de Carroll. O termo parece ter ganho uma conotação de sem sentido enquanto, na verdade, as narrativas que podem ser assim classificadas têm, sim, sentido: um sentido que pretende ser comunicado a partir de palavras cuidadosamente escolhidas. O nonsense é contrário ao absurdo, pois possui um sentido produzido por sentenças perfeitamente encadeadas. O nonsense é um sistema fechado em si mesmo, como um jogo com suas próprias regras; é, conclui Jean Jacques Lecercle em seu livro Philosophy of Nonsense, "um gênero fundamentalmente paradoxal, que, ao mesmo tempo que sustenta a regra, a subverte" (LECERCLE apud MARRET, 2003, p. 18). Como sistema, o material manipulado pelo nonsense são as palavras. Um jogo de equilíbrio entre significados diversos e que tem, por isso, seu terreno mais fértil nos trocadilhos e portmanteaux (palavras-mala ou palavras-valise). O nonsense surge do amontoado de coisas distintas que a necessidade da mente humana agrupa em um novo significado. A era vitoriana - período de grandes transformações, invenções, novidades e mudança de hábitos - tem, no gênero literário do nonsense, uma resposta a este universo de pluralidades e agrupamentos de coisas que, em princípio, parecem carecer de sentido uma em relação às outras.
} 
Os debates em forma dramática, recheados de ironia e humor, foram também utilizados por Carroll em outros - e muitos, segundo Foulkes (2005) - panfletos críticos escritos para contestar o que se passava em Oxford. O The New Belfry of Christ Church, Oxford - A Monography by D.C.L. foi publicado em 1872 e tornou-se uma leitura obrigatória em Oxford, chegando a cinco impressões (COHEN, 1998). Nele, Carroll ridiculariza a construção de um campanário que a ele parecia uma caixa de chá. No ano seguinte, Carroll valeu-se outra vez da estrutura teatral para criticar as reformas arquitetônicas de Oxford. A publicação The Vision of the Three T's - A Threnody ${ }^{19}$ vinha assinada "pelo autor de The New Belfry" (COHEN, 1998), mostrando que Carroll desconfiava ter atingido uma fiel parcela dos que frequentavam a universidade.

Esses textos - exercícios na forma teatral - antecederam o Euclides e Seus Rivais Modernos e parecem ter contribuído para a opção pelo libelo em defesa d'OS Elementos. Há ainda um outro vínculo entre o teatro - Shakespeare em particular - e Euclides e Seus Rivais Modernos: os fantasmas. Longe de serem figuras etéreas e nebulosas cujas vozes são meras imitações do vento, rouquidões assustadoras ou sussurros sibilantes, esses fantasmas dialogam, discutem de modo acalorado, tomam posições, executam ações e têm a possibilidade de alterar a vida das personagens ${ }^{20}$. Carroll faz Minos, o professor que analisará os livros dos rivais, dialogar com o fantasma do próprio Euclides e com o de um professor alemão, Herr Niemand, que, como fantasma, goza da prerrogativa fantástica e fantasmagórica de tornar-se personagens diferentes ao longo do texto, inclusive personificando alguns dos autores criticados para servir a eles como advogado de defesa. Herr Niemand não apenas leu todos os livros, mas pode transmutar-se em todos os autores enquanto participa das discussões ${ }^{21}$.

Como a personagem de Phantasmagoria - um dos poemas de Carroll - que reclama das suas condições de trabalho (sua função é assombrar casas), o fantasma de Euclides, aborrecido, relata a Minos a dificuldade no contato com os vivos:

\footnotetext{
${ }^{19}$ A Visão dos Três T's - Uma Trenodia. Os três T's referem-se à Caixa de Chá (Tea-Chest, o campanário), à Trincheira (Trench, criada com a remoção de parte da marquise do telhado para mostrar melhor o novo campanário) e ao Túnel (Tunnel, a nova entrada da catedral) (COHEN, 1998).

${ }^{20} \mathrm{O}$ exemplo mais conhecido é o do fantasma de Hamlet, mas há também fantasmas em A Tempestade, Ricardo III e Júlio César.

${ }^{21}$ Niemand significa "ninguém”, em alemão, e é interessante que esse ninguém possa, na verdade, ser vários. A brincadeira entre "ninguém" e "alguém", deve-se registrar, é comum em jogos lógicos (Ninguém chegou antes de João, que chegou na frente. Então Ninguém venceu a corrida) e foi usada, também, em outros livros de Carroll.
} 


\begin{abstract}
A raça humana é por demais estranhamente preconceituosa. Não há nada a que o homem se oponha mais enfaticamente do que a ser conduzido por fantasmas de um lugar a outro. Eu não posso dizer que eles são consistentes quanto a este assunto: estão sempre nos 'erguendo' ou 'derrubando' , pobres fantasmas - nós não podemos nem mesmo assombrar um sótão sem ter a paróquia em nossos calcanhares, empenhada para que batamos em retirada. Se $e u$ arriscasse mover um único garotinho - erguê-lo pelo cabelo até a altura de duas ou três casas, e colocá-lo de volta, são e salvo, no jardim de um vizinho - dou-lhe minha palavra: isso seria o assunto da cidade pelo próximo mês! (CARROLL, 2013, p. 41).
\end{abstract}

Se Euclides vence os rivais, a linguagem teatral - seus diálogos, marcações cênicas e personagens - põe em movimento uma série de recursos que o auxiliam nessa empreitada.

\title{
4 Um a um, caem os rivais: uma síntese
}

No roteiro da peça, ainda que Herr Niemand tente, todos os quatorze autores por ele representados sucumbem à arguição de $\operatorname{Minos}^{22}$ e à organização de Euclides. A discussão toda se passa em uma noite quando, fatigado do exaustivo trabalho de corrigir provas, com seu cabelo "despenteado, de tanto seus dedos passarem por entre os fios, como no segundo Corolário do Livro I de Euclides, 32, [suas] madeixas parecem uma auréola" (CARROLL, 2013, p. 26), Minos adormece sobre uma pilha de papéis e, em sonho, recebe a visita de Euclides. Este lhe faz, de chofre, uma pergunta tão filosoficamente ampla quanto aquela que a Lagarta faz à Alice: "O que você exige de um Manual de Geometria?" (CARROLL, 2013, p. 31). Observem que Euclides não se apresenta a Minos, não lhe diz boa noite, não lhe pergunta como vai ou o que ele está fazendo e, quando Minos lhe chama a atenção sobre isso, ele lhe responde: "nunca fui um homem de muitas palavras" (CARROLL, 2013, p. 32), uma declaração conveniente a um dos pontos que Carroll quer defender ao longo do texto - nada há de supérfluo no Manual de Euclides, nem palavras, nem figuras, nem enunciados... nada além do que aquilo que ali deveria estar.

\footnotetext{
22 "Minos" e "Carroll" praticamente se equivalem. Minos não é mero personagem de ficção, mas o próprio Carroll e seu desejo de fazer-se ouvir quanto à defesa de Euclides.
} 
Minos não conseguiria responder à pergunta de Euclides em um cochilo: ele precisa de tempo para analisar os quatorze livros dos rivais ${ }^{23}$ e, por isso, o sonho dura toda uma noite - a peça inteira -, até quando o galo canta e o dia raia (CARROLL, 2012). O sonho é um elemento narrativo importante e bastante recorrente no nonsense, pois

o sonho é verdadeiramente o produto, a criação (no sentido subjetivo ou objetivo) de um universo pessoal que tem sentido somente para quem o criou. No limite, ele se tingirá de loucura para os que não entrarão nele. A sabedoria popular o exprime claramente quando dizemos a um interlocutor: 'Você está sonhando!' não é mais do que uma maneira educada de fazê-lo entender que está louco. Deste modo, aquele que sonha projeta em seu sonho as ideias que estão no fundo de sua consciência, as hipóteses que ele constrói a partir de premissas fantasiosas e segundo um mundo de raciocínio que não é aquele do mundo desperto; é quase inevitável que o resultado destas elocubrações pareça, às vezes, demência àqueles que vêm a conhecê-lo. De sonhador a louco há somente um pequeno e fácil passo a dar para aqueles que não sonham (GATTEGNO, 1990, p. 91) ${ }^{24}$.

O sonho não é somente fundamental como opção estilística de Carroll, mas como cenário para que, nas palavras de Gattegno, Minos possa fazer suas escolhas, conduzir seus argumentos, seguir sua própria lógica, ser sarcástico, usar metáforas e até mesmo encontrar outros fantasmas que compartilham a cena. Este grande e longo sonho é um mundo que encapsula Minos e dá a ele autoridade e condições para analisar os livros - as modificações em relação a Os Elementos, a omissão de certas proposições, a inserção de outras e a substituição de provas existentes por outras novas - que, ainda que constatadas, não resultariam no abandono do manual de Euclides, pois conforme declara seu autor-fantasma, isso tudo "um professor poderia fazer, desde que a sequência lógica permanecesse completa" e "outras provas sempre podem ser dadas, passando a integrar o sistema como "provas alternativas'" (CARROLL, 2013, p. 37). As duas únicas modificações nos livros dos rivais que, caso encontradas, seriam prerrogativas para que pudessem ocupar o lugar de Euclides são a organização de

\footnotetext{
${ }^{23}$ Sendo comum usar "Euclides" como sinônimo de "Os Elementos, de Euclides", também o texto de Carroll joga com essa possibilidade: os rivais tanto podem ser os autores (rivais de Euclides, portanto) como seus livros (rivais d'Os Elementos).

${ }^{24} \mathrm{O}$ sonho, pelas (im)possibilidades que abre aos personagens, ajusta-se bem às narrativas nonsênsicas: ambas as aventuras de Alice se passam durante um sonho; em A Caça ao Turpente, é somente num sonho que o Conselheiro vê o monstrengo, pois ele nunca aparece ao longo do poema; nas aventuras de Sílvia e Bruno, os personagens do mundo real encontram os do imaginário quando estão dormindo ou em vigília; em Através do Espelho e o que Alice Encontrou Lá há um paradoxo circular bastante comentado: Alice sonha com o Rei Vemelho, que está sonhando com Alice, que está sonhando com o Rei Vermelho, que está sonhando com Alice...
} 
problemas e teoremas - entenda-se aqui a mudança na ordem dos conteúdos expostos ${ }^{25}$ - e o modo como tratam o tema das paralelas. As regras para a apreciação dos rivais são cuidadosa e explicitamente discutidas, sistematizadas, estabelecidas, sintetizadas e enunciadas antes mesmo que a avaliação de cada manual se inicie: não se poderia esperar algo diferente de Euclides.

Um dos pontos principais do texto elaborado por Carroll, segundo essa nossa leitura, é que qualquer um dos rivais, na sua proposta de substituir Euclides como manual para o ensino da geometria, deveria ser lógica e adequadamente organizado para os alunos iniciantes. Não cabe aqui discutirmos se Os Elementos eram ou não adequados - sabe-se que Carroll pensava que sim, e isso basta a este exame hermenêutico -, mas entender por que, segundo o texto de Carroll, os livros dos rivais são tidos como inadequados para ensinar geometria àqueles que nada, ou pouco, sabiam dela.

Antes mesmo de apresentar Minos a Herr Niemand, Euclides descreve panoramicamente os livros da época:

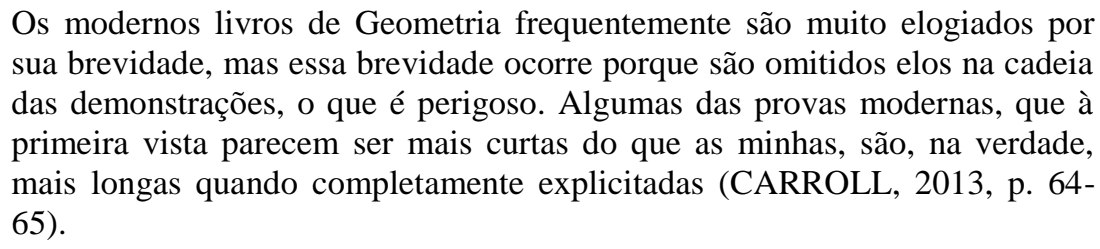

Com relação ao tema das paralelas, o que se discute é o teste prático dado por Euclides em seu axioma que permite verificar que duas retas finitas se encontrarão quando prolongadas se, ao serem intersectadas por uma transversal, fazem com esta dois ângulos internos do mesmo lado que, juntos, somam menos que dois retos. O Axioma de Playfair ${ }^{26}$, adotado por muitos dos rivais, não fornece, segundo o fantasma de Euclides, um teste para verificar se duas retas são paralelas, pois baseia-se apenas na observação delas, sem oferecer uma possibilidade matemática para verificar se elas se aproximam ou não:

Se precisamos de uma concepção clara sobre a relação geométrica das duas retas, em cuja interseção 'futura' somos solicitados a acreditar, qual cenário, você acha, é mais adequado para nos dar uma tal concepção: duas retas finitas, ambas intersectadas por uma transversal, ambas satisfazendo uma

\footnotetext{
${ }^{25}$ Em várias tabelas (apresentadas no quarto Apêndice), Carroll compara o livro de Euclides com cada um dos outros, mostrando quais teoremas e corolários tinham correspondentes nos livros dos rivais e quais foram suprimidos etc.

${ }^{26}$ O Axioma de Playfair é a contrapositiva do de Euclides: Por um ponto dado fora de uma reta dada é possível traçar somente uma reta paralela à primeira.
} 
relação angular conhecida com aquela transversal e também entre si; ou duas retas 'que sabemos serem paralelas', isto é, duas retas de cujas relações geométricas nada sabemos, até onde nosso campo de visão alcança, mas podemos dizer apenas que, na remota região do infinito, elas não se encontram? (CARROLL, 2013, p. 59).

Os demais testes apresentados se perdem em definições, classificações e diagramas que o estudante não consegue "nem definir, nem construir, nem testar" (CARROLL, 2013, p. 117).

\begin{abstract}
O método infinitesimal, tão graciosamente empregado por M. Legendre, é inadequado para iniciantes; o método das transversais e o método por retas em revolução ainda não foram apresentados de forma lógica; o método de equidistâncias é demasiadamente incômodo; e o método da direção é, simplesmente, como um castelo de areia - se esfacela onde quer que você o toque! (CARROLL, 2013, p. 202).
\end{abstract}

O livro de Legendre é considerado "refinado" mas "menos belo", pois não atende às necessidades de um iniciante. No livro de Euclides, "linha [reta] é comprimento sem largura" (EUCLIDES, 2009, p. 97), enquanto Legendre define a linha reta como "a menor distância de um ponto a outro", ou seja, define-a baseada em sua magnitude, noção que Euclides não mobiliza em todo o Primeiro Livro. Minos diz que "o comprimento de uma linha é um assunto assaz difícil para um iniciante; além disso, não é necessário que ele o considere, pelo menos nos estudos iniciais de Geometria" (CARROLL, 2013, p. 73) e que as provas de Legendre mobilizam uma série infinita de triângulos e ângulos cujos valores decrescem até serem menores do que qualquer ângulo indicado, e cujas magnitudes, assim, simplesmente desaparecem. O livro merece, apesar de tudo, um elogio da personagem: "seu lindo tratado, como um todo, é admiravelmente adequado para alunos avançados" (CARROLL, 2013, p. 73).

O livro de Cooley apresenta "a solenidade verbal de uma lógica vazia"28 (CARROLL, 2013, p. 76). Com o intuito de ser um livro mais resumido e direto, ele apresenta os elementos da geometria plana em apenas 36 proposições que abrangem, segundo o autor em seu prefácio, quase que totalmente as 173 proposições contidas nos seis primeiros livros de Euclides; além desta dilaceração - que para Minos obviamente compromete o encadeamento lógico dos conteúdos -, o autor também omite os problemas, defendendo que a ciência da Geometria sustenta-se totalmente nos teoremas. O método das transversais apresentado no livro esfacela-se facilmente, pois enunciado

\footnotetext{
${ }^{27}$ Fine by degrees, and beautifully less (Quanto mais refinada, menos bela) é a epígrafe que Carroll usa para o tópico relativo à análise do livro de Legendre.

${ }^{28}$ Esta é a epígrafe com a qual Carroll abre o Ato III, Cena III: the verbal solemnity of a hollow logic.
} 
como "retas são ditas paralelas quando são igualmente inclinadas com relação à mesma reta, ou quando fazem, do mesmo lado, ângulos iguais" (CARROLL, 2013, p. 78), não oferece nenhum método de comprovação. A afirmação de Euclides é na ordem contrária: "caso uma reta, caindo sobre duas retas, faça os ângulos alternos iguais entre si, as retas serão paralelas entre si” (EUCLIDES, 2009, p. 119), ou seja, de início já temos a transversal dada e, a partir daí, classificamos o par de retas como sendo formado por paralelas ou não. Cooley sugere começarmos pelas retas: se as retas de um par são paralelas - mas como saber que o são? -, então há uma transversal que a intersecta, uma transversal com a qual as retas fazem, do mesmo lado, ângulos iguais uma transversal, mas qual transversal? E por onde ela passa? Minos questiona seu oponente: "Não podemos desenhar uma transversal ao acaso e dizer 'esta é uma reta que faz ângulos iguais com o par de retas', podemos?" (CARROLL, 2013, p. 78), e assim dá por encerrado esse assunto.

Henrici, outro dos "rivais", toma bem mais tempo de Minos, que classifica o livro como uma olla podrida ${ }^{29}$, "pois o conteúdo parece estar irremediavelmente misturado. A maioria dos axiomas e todos os teoremas estão sem numeração e, como não há índice, é óbvia a dificuldade de encontrá-los quando se deseja" (CARROLL, 2013, p. 103). Além disso, seguindo as tendências modernas da época, o livro começa com algumas páginas de considerações gerais e assuntos como Tempo e Força, Cinética e Cinemática, Química e Biologia “atravessam a seção numa esplêndida, mas obscura, procissão" (CARROLL, 2013, p. 97), deixando o aluno "suficientemente esmagado pelo espetáculo do que há por conhecer" (CARROLL, 2013, p. 97).

Este rival contém vários erros conceituais e outros relativos ao encadeamento do raciocínio lógico que não são poupados por Minos, além de definições distintas para a mesma coisa, como as definições de reta, lidas por Niemand: "a fronteira de uma superfície ou parte de uma superfície é chamada reta ou curva" (CARROLL, 2013, p. 86) e, também, "se suspendemos um peso por um barbante, o barbante fica esticado, e dizemos que ele está reto" (CARROLL, 2013, p. 89). O diálogo que se segue exemplificará, mais uma vez, a incompreensível escolha de termos de Henrici para a definição de reta e curva. Niemand ainda tenta salvar seu livro, mas Minos não o poupa:

\footnotetext{
${ }^{29}$ Olla podrida é um típico prato espanhol feito com carnes e legumes variados (que também pode ser chamado de "puchero" ou "cocido"). Em Portugal e no Brasil, o prato (ou uma variação dele) é chamado "cozido".
} 
Nie. (...) A primeira definição que consigo encontrar é a de curva. Ele (Henrici) diz "um ponto pode ser movido e, assim, ele descreverá um caminho. Este caminho do ponto em movimento é chamado curva".

Min. Certamente ele não quer dizer que um ponto nunca possa se mover em linha reta, certo? Imagino que queira dizer que há dois tipos de curvas, as "curvas curvadas" e as "curvas retas" - como os Irlandeses dizem 'tay-tay" e 'coffee-tay' ${ }^{30}$. Mas, se é assim, ele trata 'retas' e 'curvas' como sinônimos.

Nie. Dei uma olhada um pouco mais à frente e encontrei uma descrição de 'linha' que parece limitar-se a indicar as linhas curvas. Ele diz: 'a ideia de linha pode ser obtida ao considerar-se um fio curvado em qualquer forma, abstraindo dele toda a sua espessura'.

Min. Então uma 'linha' deve ser curvada, embora uma 'curva' não precise ser desta forma? Seu cliente ${ }^{31}$ tem indiscutivelmente $u m$ mérito: a grande originalidade de estilo!

Nie. Aqui está outra definição de 'curva' que talvez lhe agrade mais: 'Uma curva é uma extensão de mão-única que tem pontos como elementos’.

(CARROLL, 2012, p. 87-88)

E, se em algumas partes sobram palavras, parece que em outras elas faltam. Quando Henrici afirma que, se dois planos têm dois pontos $A$ e $B$ em comum, eles precisam, necessariamente, ter mais pontos em comum, pois, uma vez que os planos são ilimitados, um ponto que se movesse por $A$ ou por $B$ cortaria o outro plano neste ponto (o que provaria que os planos se intersectam), ele se esquece de ressaltar que os dois planos têm que ser distintos. Quando ele afirma que "se duas retas são, cada uma, perpendicular a uma terceira, elas são paralelas entre si" (CARROLL, 2013, p. 102), se esquece de dizer que as retas em questão devem ser não-coincidentes. Estes e outros descuidos de Henrici são belos presentes para Carroll que, tendo tido um cuidado todo especial com o significado das palavras ao longo dos seus escritos, sabe bem usá-las para apontar as falhas desse rival. Já o caso das paralelas, segundo Minos, Henrici trata de forma confusa e incompleta, falando de raios com cabeças e rabos (semirretas, na verdade). Para verificar a existência de paralelas, deve-se rotacionar estes raios e ver se eles intersectam ou não uma reta dada. A análise de Minos termina com a sentença: "Nunca encontrei qualquer coisa mais desesperançadamente ilógica" (CARROLL, 2013, p. 96).

O método das equidistâncias de Cuthbertson, classificado anteriormente por Minos como demasiadamente incômodo, não é refutado por erro de encadeamento ou

\footnotetext{
30 O autor faz uma "brincadeira" com a maneira como os não-ingleses falantes da língua inglesa pronunciam o idioma - neste caso, a brincadeira é com a pronúncia dos irlandeses. "Tay-tay" refere-se a "tea-tea" (chá-chá) e "coffee-tay" a "coffee-tea", referindo-se ainda ao modo como os irlandeses antigos se referiam ao café, chamando a bebida de "chá de café".

${ }^{31}$ Niemand, o "ninguém" que assume as defesas/o lugar dos rivais, é chamado de cliente dos "rivais", pois a ele foi dada a função de protegê-los dos ataques de Minos.
} 
de definições, mas por requerer, do estudante, uma gama maior de conhecimentos. Este rival segue, para verificar que duas retas dadas são paralelas, a seguinte ordem: (1) prova que a distância mais curta entre dois pontos é uma linha reta; (2) prova que, de todas as linhas retas desenhadas de um ponto até outra linha reta, a perpendicular é a menor; (3) deduz, então, que a perpendicular é o caminho mais curto entre um ponto e uma linha reta; (4) define distância entre pontos e distância de um ponto a uma reta como o menor caminho entre eles; (5) reorganiza tudo na afirmação "a distância entre um ponto e uma linha reta é o comprimento da perpendicular que, do ponto dado, cai sobre ela"; (6) introduz o axioma "se uma reta é desenhada no mesmo plano que outra, ela não pode, com relação a esta outra, primeiro afastar-se e depois aproximar-se dela, tampouco pode primeiro aproximar-se e depois afastar-se dela"; (7) apresenta o lema "por um ponto dado que não pertence a uma reta dada, uma e somente uma reta pode ser desenhada no mesmo plano que a anterior, de modo que nunca a encontre. Os pontos em uma dessas retas são todos, também, equidistantes da outra"; e, por fim, (8) introduz a definição de paralelas de Euclides, dizendo que "é naturalmente óbvio que as retas paralelas são equidistantes e que retas equidistantes são paralelas". Um longo percurso que faz a arte de sua organização ficar tão próxima e, ainda assim, tão distante ${ }^{32}$ do equivalente resultado apresentado por Euclides... Minos abandona também esta obra, apesar de reconhecê-la clara e bem escrita, justificando: "a novidade principal do livro é a introdução do princípio de 'equidistância', o que não me parece uma característica desejável num livro destinado a iniciantes. Por outro lado, este manual nada mais é do que uma versão um pouco modificada do livro de Euclides" (CARROLL, 2013, p. 85).

O tratamento das paralelas envolvendo direção é um caso mais delicado e engloba três rivais: Wilson, Pierce e Willock.

No início da análise da obra de Wilson, Niemand pede a Minos que seja cauteloso em suas críticas, pois esta já havia sido adotada em várias escolas. Coincidentemente ou não, este é o maior capítulo de Euclides e Seus Rivais Modernos. No livro de Wilson, a reta é definida como "uma linha que tem a mesma direção em todas as partes do seu comprimento. Ela tem, também, direção oposta. Uma linha reta pode ser concebida como gerada por um ponto que se move sempre na mesma direção" (CARROLL, 2013, p. 113). Depois disso, Wilson (isto é, Niemand assumindo a posição

\footnotetext{
${ }^{32}$ Thou art so near, and yet so far é a epígrafe que Carroll utiliza para apresentar este livro, no Ato II, Cena IV.
} 
de Wilson) tenta convencer Minos de que retas paralelas são aquelas que, sem ter nenhum ponto em comum, têm a mesma direção - outra vez a discussão se desdobrará na busca das palavras adequadas que ajudarão o iniciante a formar o raciocínio adequado. Minos nega que a expressão mesma direção possa ser usada para duas retas disjuntas, sendo esta aplicável somente para retas coincidentes, apresentando os seguintes argumentos:

Min. Eu preferiria dizer que as retas disjuntas têm direções 'colaterais' (ou 'correspondentes' ou 'distintas' ) a usar a expressão 'a mesma direção' novamente. É verdade que direções 'colaterais' produzem os mesmos resultados que direções 'iguais' no que concerne aos ângulos formados com uma transversal, mas isto me parece ser um teorema, não um axioma.

Nie. Você diz que a relação não lhe parece ser idêntica. Eu gostaria de saber onde você acredita perceber qualquer diferença?

Min. Tentarei fazer-me mais claro com uma ilustração.

Imagine que eu e vários colegas estejamos caminhando ao longo de um trilho de trem que nos levará a um lugar que desejamos visitar. Alguns se divertem caminhando sobre um dos trilhos, alguns sobre o outro, e outros vagueiam pelo mesmo caminho, indo para lá e para cá. Como todos rumamos para o mesmo lugar, podemos dizer, falando grosseiramente, que todos estamos nos movendo na 'mesma direção' - falando de forma muito grosseira, realmente. Nossa linguagem será mais exata se excluirmos os que vagueiam e dissermos que apenas aqueles que estão caminhando sobre os trilhos estão se movendo. Mas me parece que nossa afirmação se torna ainda mais acurada se nos referirmos apenas àqueles que caminham sobre um único trilho.

Como uma segunda ilustração, imagine duas forças agindo sobre certo corpo, e pense-as como sendo iguais em intensidade, mas com direções opostas. Se elas estiverem agindo ao longo da mesma reta, sabemos que elas se neutralizam e que o corpo permanece em repouso. Mas se uma for deslocada um pouquinho para um lado, então estarão atuando ao longo de retas paralelas e, por isso, embora ainda iguais em intensidade e (de acordo com a teoria da 'direção') com direções opostas, elas não se neutralizam mais, mas formam uma 'dupla' .

Como uma terceira ilustração, tome dois pontos de um certo plano. Podemos, primeiro, desenhar uma reta que os contenha e fazê-los se mover ao longo dela: eles sem dúvida estão, então, se movendo 'na mesma direção'. Podemos, em segundo lugar, desenhar, pelos pontos, duas retas que se encontram ou que virão a se encontrar se prolongadas, e movimentá-los sobre estas retas: eles estão, então, sem dúvida, se movendo em 'direções diferentes' . Podemos, em terceiro lugar, desenhar, pelos pontos, duas retas paralelas e movimentá-los ao longo delas. Seguramente esta é uma nova relação de movimento, não absolutamente idêntica a nenhuma das duas anteriores, certo? Mas, se esta nova relação não for absolutamente idêntica àquela chamada de 'na mesma direção', ela deve pertencer à classe chamada 'direções diferentes' (CARROLL, 2013, p. 119-120).

A discussão recomeça por outro lado, e Minos e Niemand concordam em dividir todos os pares de retas não-coincidentes em duas classes: as que se intersectam e as que são disjuntas. Niemand, defendendo Wilson, pergunta a Minos se ele admite que retas 
que se intersectam têm direções diferentes, ao que ele responde positivamente, mas acrescenta que disso não é possível concluir que retas disjuntas têm a mesma direção.

\footnotetext{
Min. Por que não posso dizer que retas que se intersectam têm um tipo de 'direções diferentes' e que retas disjuntas têm outro?

Nie. Mas você o diz?

Min. Certamente não. Não há evidência, até o momento, de uma coisa ou outra. (CARROLL, 2013, p. 122)
}

Parece implicância de Minos, mas aí reside a questão: Wilson não consegue provar o que afirma e, como um castelo de areia, o método da direção se desmancha quando Minos o toca. Como se não bastasse isso, o livro já adotado por muitas escolas apresenta erros graves, capazes de assustar até mesmo o fantasma de Euclides, como os dos exemplos a seguir: o corolário 1 - "se duas retas não paralelas são intersectadas por uma terceira, os ângulos alternos não serão iguais e os ângulos internos do mesmo lado da reta de interseção não serão suplementares" - torna-se falso se tomarmos duas retas não paralelas que sejam coincidentes; a afirmação "se um círculo tem um ponto interno a outro círculo, as circunferências se intersectarão" é inexata, pois as circunferências poderiam ser concêntricas; é pedido que se "encontre um ponto igualmente distante de três retas dadas", o que é impossível fazer sem deixar claro que as retas em questão não são paralelas... Wilson, devido aos "abundantes exemplos de imprecisão lógica e o uso de linguagem inadequada (...), não tem condições ser adotado como $o$ manual para o ensino e para os exames" (CARROLL, 2013, p. 144).

Chega a vez de Pierce $^{33}$, autor cujo esforço para ser breve resulta em obscuridade $^{34}$. Sua definição "a direção de uma reta em qualquer parte é a direção entre o ponto desta parte e o ponto seguinte" não resiste à arguta pergunta de Minos sobre $a$ qual distância de um ponto deve estar o próximo para satisfazer esta definição. Sua resposta (ou a resposta de um Niemand tornado Pierce) - "numa distância infinitamente pequena, naturalmente. Você encontrará o assunto amplamente discutido em qualquer trabalho de Cálculo Infinitesimal" (CARROLL, 2013, p. 146) - é tudo o que o representante de Euclides precisa ouvir para sentenciá-lo: é um manual útil para um aluno avançado, mas inadequado para um iniciante.

\footnotetext{
${ }^{33}$ Trata-se de Benjamin Pierce, pai de Charles Sanders Pierce.

${ }^{34}$ Carroll apresenta este livro no Ato II, Cena VI, com a epígrafe "dum brevis esse laboro, obscurus fio", de Horácio.
} 
O livro de Willock, em cujo prefácio o autor já admite ter algumas falhas ${ }^{35}$, introduz uma definição nova - diretriz é o termo associado a retas infinitas - mas incorre no mesmo e fatal erro do livro de Wilson: o autor não consegue demonstrar a existência de retas discodais ${ }^{36}$ para validar seus teoremas de números 8 (os ângulos de intersecção de uma transversal com duas diretrizes discodais são iguais) e 10 (se uma transversal intersecta duas diretrizes e faz, com elas, ângulos de intersecção iguais, as diretrizes são discodais), dentre outros; quando não consegue provar a existência de uma classe de retas que contenham estas características, suas afirmações não passam de adivinhações e quimeras. Além do tratamento pela direção - que, neste ponto, já desabou -, Minos ainda faz fortes críticas com relação à organização do livro de Willock, cujo primeiro capítulo traz figuras demasiadamente complicadas e cuja teoria das tangentes depende do movimento das retas e do desaparecimento de cordas: "tudo bastante desalentador para um iniciante" (CARROLL, 2013, p. 152).

\begin{abstract}
Min. Depois vem um capítulo de problemas e então, quando seu aluno tiver logrado êxito em dominar 34 páginas do seu livro, e tiver razoavelmente se familiarizado com tangentes, segmentos, diâmetros, ângulos reentrantes, 'formas ovais' , 'formas semi-convexas e semi-côncavas', você finalmente o confronta com o mais abstruso e terrível teorema: o Euclides I 4! (CARROLL, 2013, p. 152).
\end{abstract}

Minos classifica Willock como o livro com a pior organização dentre os que analisou até o momento e, abandonando-o, parte para os outros rivais modernos - o Ato III desse espetáculo carrolliano. O que caracteriza este novo Ato é que os demais autores (Chauvenet, Loomis, Morell, Reynolds, Wright, o Manual da Associação para a Melhoria do Ensino de Geometria ${ }^{37}$ e o Programa-Manual de Wilson ${ }^{38}$ ) adotam o

\footnotetext{
${ }^{35}$ This work (...) no doubt, has its faults é uma frase do próprio Willock, em seu prefácio, usada por Carroll como epígrafe para apresentar este livro no Ato II, Cena VI, § 3.

${ }^{36}$ Esta "palavra-mala" é usada por Carroll para referir-se às retas que não têm nenhum ponto em comum (dis é a primeira sílaba de disjuntas) e são codirecionais (de onde vêm o prefixo cod e o plural ais).

${ }^{37}$ Como resultado das reformas na educação inglesa da época, em 1871 foi criada a Association for the Improvement of Geometrical Teaching (AIGT), que se mostrou particularmente preocupada com a proliferação dos livros-texto e com os exames aos quais os alunos eram obrigatoriamente submetidos: como avaliar com justiça a explicação ou numeração das proposições se o candidato tivesse estudado por outros sistemas e livros? Uma das preocupações principais da AIGT passou a ser a elaboração de um novo livro-texto de Geometria, com vistas a substituir a pletora de livros existentes. Em sua organização original, a AIGT teve Thomas Hirst (1830-1892) como seu primeiro presidente, Wilson como um dos dois vice-presidentes e R. Wormell como tesoureiro - Wilson e Wormell publicaram, à época, livros de geometria. O primeiro manual da AIGT continha somente os livros de Euclides do primeiro ao quarto, e foi apoiado pela BAAS (British Association for the Advancement of Science), mas a BAAS queria que a AIGT produzisse um texto que contivesse até o sexto livro, intento alcançado somente em 1876.

${ }^{38} \mathrm{O}$ que Carroll chama de Programa-Manual de Wilson é o livro Elementary Geometry, no qual Wilson seguia rigidamente o programa proposto pela AIGT.
} 
tratamento de Euclides para o estudo das paralelas. Minos sabe (Carroll sabe) que, devido a isso, "nenhum pequeno ponto de diferença pode justificar o abandono de nosso velho amigo em favor de qualquer Rival Moderno" (CARROLL, 2013, p. 156), mas faz questão de mostrar que estes livros não merecem ocupar o lugar de Euclides, mesmo tratando o assunto tal qual ele faz. É interessante ressaltar aqui a epígrafe escolhida - de uma obra de Shakespeare, mais uma vez - para este capítulo: But mice, and rats, and such small deer / Have been Tom's food for seven long year ${ }^{39}$. Small deer (cuja tradução literal é pequeno veado ou, por extensão, pequeno animal) é expressão que indica algo quase inútil, que não vale a pena perder tempo perseguindo, o que Carroll demonstra na própria composição destes capítulos: todos eles são curtos e bastante diretos se comparados aos anteriores, dando a impressão de que tanto quanto os próprios livros, são small deers as alterações que sugerem.

Não há muito que comentar sobre os livros de Chauvenet e Loomis. Para o primeiro, Minos, depois de sugerir apenas que algumas das novas proposições que o autor apresenta sejam interpoladas como exercícios ao livro de Euclides, declara que não tem "outros comentários a fazer sobre este livro, que parece claramente redigido" (CARROLL, 2013, p. 159); sobre o segundo, cujas proposições aparecem quase na mesma ordem que as de Euclides, diz que também não tem muitas críticas negativas a fazer, mas que o livro não passa de um Euclides modernizado, adotando, meramente, o axioma de Playfair e omitindo as diagonais tratadas no segundo livro d'Os Elementos.

O próximo rival, Morell, era membro de uma organização que inspecionava as escolas a serviço de Sua Majestade. Dado o abandono do livro de Euclides em diversos países e as observações do governo francês sobre a educação vitoriana ${ }^{40}$, o livro deste autor tinha por nome "Euclides Simplificado, Compilado dos Mais Importantes Estudos Franceses, Aprovado pela Universidade de Paris pelo Ministério Público de Instrução".

\footnotetext{
${ }^{39}$ Esta citação é uma fala de Rei Lear (Ato III, Cena IV), de Shakespeare. Na tradução de Millôr Fernandes e Beatriz Viégas-Faria (William Shakespeare - obras escolhidas, Porto Alegre: L\&PM, 2008), ela é dita pelo personagem Edgar como "Mas só ratos, camundongos / E mais bichinhos assim / Foram a comida de Tom / Por sete anos sem fim". "Year", que deveria estar no plural (ainda que no singular se preserve o ritmo da rima com “deer"), aparece no singular na edição original de Euclides e Seus Rivais Modernos.

${ }^{40} \mathrm{Na}$ França, onde se adotara o livro Élements de Géometrie de Legendre, Jacques Demogeot e Henry Montucci, que haviam sido enviados em 1866 para a Grã-Bretanha a fim de analisarem aquele sistema de ensino, publicaram o resultado de suas pesquisas comparativas, apontando que, na Inglaterra, o uso de Euclides como livro-texto exercitava somente a memória, não a inteligência, e que sua lógica era robusta, mas seu tratamento era tedioso.
} 
Voltando-se à pompa do título e ao cargo ocupado por seu autor, Carroll indaga: "Quem vigia os vigilantes? Quem inspeciona os inspetores?"41.

A primeira falha do livro de Morell aparece logo na definição de reta - uma "linha indeterminada, a menor entre quaisquer dois de seus pontos" - que é avaliada como afirmação sem sentido, pois o autor não explica o que entende por indeterminada e permite ao leitor pensar que uma curva é mais facilmente determinada que uma reta. Ainda sobre retas, Morell define que "uma linha quebrada é uma linha composta de linhas retas", mas uma linha reta também é composta por partes retas. Além disso, segundo o autor, "a figura formada por duas retas que se cruzam é chamada ângulo", embora tivesse anteriormente definido "figura" apenas como "o nome dado a volumes, superfícies e retas" (“ângulo", obviamente, não se encaixando em nenhuma destas três classificações). Há outras muitas afirmações equivocadas deste "inspetor" que, segundo a "inspeção" de Minos, deveriam ser alteradas em seu livro: "duas retas perpendiculares à mesma reta são paralelas" (Minos indica que é preciso ressaltar que estas retas são distintas), "a base de um triângulo isósceles é o lado desigual" (se essa definição tivesse algum sentido, segundo Minos, os triângulos equiláteros deveriam ser excluídos da classe dos isósceles) etc.

Na fila de rivais, chega a vez de Reynolds. Seu livro também é salpicado de small deers tais como assumir, sem nenhuma prova, que "paralelas são equidistantes uma da outra". Entretanto, os erros mais graves que Minos aponta são que "as definições e axiomas estão espalhados pelo livro ao invés de estarem juntos, no começo, e não há índice algum, de forma que o leitor somente chega a eles por acaso" (CARROLL, 2013, p. 172) e que os teoremas do segundo livro d'Os Elementos, em Reynolds, são provados algebricamente, o que a Minos parece "uma mudança para pior, principalmente porque conduz ao difícil tema das magnitudes incomensuráveis" (CARROLL, 2013, p. 173). Dos primeiros dois livros de Euclides, Reynolds abandona um total de quinze proposições, de modo que sua obra, assim organizada, parece, para os iniciantes, "uma loucura, embora tenha lá seu método" ${ }^{42}$. Mais um rival que cai...

Wright chega à cena já com um pouco de descrédito, uma vez que ele mesmo assume, no prefácio de seu livro, que, inquestionavelmente, sua obra tem defeitos de

\footnotetext{
${ }^{41}$ Quis custodiet ipsos custodes? Quis inspiciet ipsos inspectores? é a epígrafe que Carroll para o tópico que discute este livro, no Ato III, Cena I, § 4.

${ }^{42}$ Though this be madness, yet there's method in't é a epígrafe de Carroll para o Ato III, Cena I, $§ 5$.
} 
execução ${ }^{43}$. No entanto, contrariando esta declaração de humildade, segundo Minos, Wright "reivindica crédito por ter mais axiomas do que Euclides, a quem ele culpa por ter demonstrado 'muita coisa óbvia' " (CARROLL, 2013, p. 174).

Todos estes autores - Chauvenet, Loomis, Morell, Reynolds, Wright - e suas obras têm, para Minos, mérito bastante questionável. Entre pequenas modificações e alguns erros sérios, ele encerra esta cena declarando: "com relação a estes cinco autores, posso dizer que, para mim, eles não parecem trazer nenhuma novidade desejável que possa ser facilmente introduzida numa edição corrigida de Euclides" (CARROLL, 2013, p. 177). Niemand, seu interlocutor, não consegue contestar essa afirmação.

A última cena deste ato trata dos dois que talvez sejam os principais rivais de Euclides: o Manual da Associação para a Melhoria do Ensino de Geometria e o Programa-Manual de Wilson, ambos livros de 1878, indicados fortemente pela AIGT para substituir Os Elementos. Para analisá-los, Minos diz que gostaria de conversar com algum membro da AIGT:

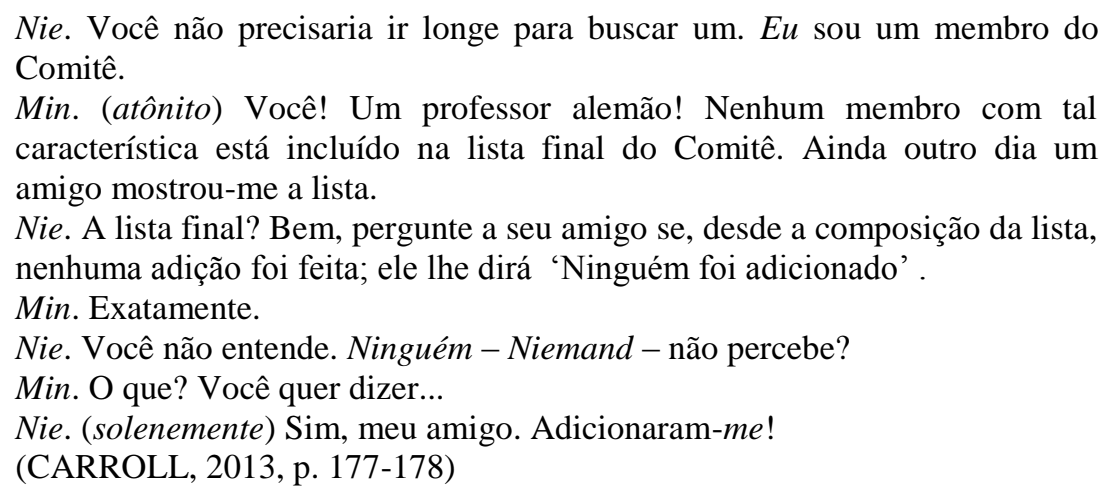

Ao assumir-se como membro do Comitê, Niemand adota então nova identidade e passa a se chamar Nostradamus, nome que Minos não deixa de comentar: Nostradamus, do latim, pode significar nós damos o remédio de um charlatão. A cena deixa bem clara a crítica de Carroll (Calvino afirma que o nome de uma personagem amalgama-se a seus atos) e a observação sagaz de Minos que, já nesta ressalva, desqualifica o manual da AIGT.

O primeiro erro do Manual da Associação aparece já na definição de reta: "uma reta é tal que qualquer parte, onde quer que seja colocada, ficará totalmente sobre qualquer outra parte, quando suas extremidades são colocadas naquela outra parte", que

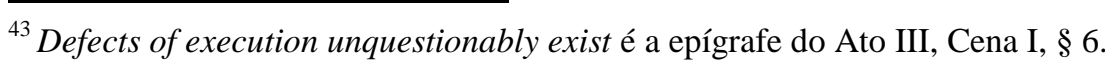


Euclides toma como axioma, julgando ser esta uma propriedade da reta ${ }^{44}$, e não sua essência. Nostradamus tenta justificar-se: "Bem, você percebe que havia muitos de nós organizando este Manual e ele acabou um pouco misturado: não sabemos bem quais são as definições e quais são os axiomas" (CARROLL, 2013, p. 181). Nos numerus sumus $^{45}$ : tantas mãos e tantas penas resultando em tanta confusão.

Há, segundo a análise de Minos, erros por todos os lados, muitos deles devido ao uso inadequado das palavras, um campo em que Carroll passeia sem dificuldades. Quando, por exemplo, o manual define ângulo plano como aquilo que está contido ou é formado por duas retas desenhadas a partir do mesmo ponto, Minos pergunta como se chamaria aquilo contido ou feito por duas retas desenhadas para um mesmo ponto: "Um ângulo, indubitavelmente", responde Nostradamus, dando-se conta de toda uma classe de ângulos que a definição do manual omitira. "Quando uma reta encontra outra reta e faz com esta os ângulos adjacentes iguais, cada um dos ângulos é chamado ângulo reto", outra definição inadequada: Minos desenha um segmento reto $A C$, marcando $B$ em algum ponto entre os extremos, o que origina duas retas $(A B$ e $B C)$ cujos ângulos adjacentes são rasos, e não retos; o livro define que "todos os outros triângulos são acutângulos" duas páginas antes de provar que não é possível haver um triângulo com dois ângulos retos, e prova o teorema "retas paralelas com projeções iguais sobre outra reta são iguais" sem considerar que, se as retas fizerem ângulos retos com outra reta, suas projeções serão iguais (ambas nulas), independentemente de serem iguais ou não. Por estes e outros enfrentamentos, Nostradamus descontrola-se e exclama: "Não diga mais nada! Minha cabeça está rodando!” (CARROLL, 2013, p. 186).

O fato de os teoremas das primeiras 26 proposições de Euclides aparecerem em outra ordem - primeiro estão dispostos os três relativos a retas e, depois, todos os demais, relativos aos triângulos - é o único ponto que agrada a Minos neste manual, o que de pouco vale se comparado às modificações com resultados desastrosos, como a separação dos teoremas dos seus recíprocos.

Imaginamos Minos já bastante exausto. Com grande conhecimento de Euclides e raciocínio bastante apurado, ele derrubou doze rivais e o manual da AIGT (que, por si só, representa um grupo de vários outros rivais). Antes que o dia amanheça, antes que

\footnotetext{
${ }^{44}$ E linha reta é a que está posta por igual com os pontos sobre si mesma (EUCLIDES, 2009, p. 97).

${ }^{45}$ Do Livro I, Epístola II das Epístolas de Horácio vem essa epígrafe que Carroll usa no Ato II, Cena II, $\S 1$, criticando os membros da AIGT que, em sua opinião, apesar da quantidade, não fizeram um trabalho relevante.
} 
Minos desperte, porém, deve haver tempo para um último combate: a análise do Programa-Manual de J. M. Wilson, um dos membros fundadores da AIGT. A discussão é rápida, pois Minos já derrubara vários argumentos dos livros anteriores cujas questões reaparecem neste e, além disso, ele mostra que praticamente todo o conteúdo organizado por Wilson aparece tal e qual em Os Elementos, apenas em outra ordem. Apesar da grave "lacuna comum dos sistemas que substituem o axioma de Euclides pelo de Playfair ${ }^{46 ", ~(C A R R O L L, ~ 2013, ~ p . ~ 192), ~ M i n o s ~ d e s t a c a ~ n o ~ l i v r o ~ u m ~ p o n t o ~ p o s i t i v o: ~ a ~}$ teoria relativa à direção foi totalmente ignorada. Isto, no entanto, não o salva da retaliação, como se pode ver pela sentença final do defensor de Euclides:

Recordando algumas das proposições de Euclides I e II ${ }^{47}$ e incluindo alguns
dos corolários, obtemos 73 proposições ao todo: 57 teoremas e 16 problemas.
Destas 73 , este Manual omite 14 (10 teoremas e 4 problemas), prova 43 ( 32
teoremas e 11 problemas) usando métodos quase idênticos aos de Euclides,
oferece para 10 delas ( 9 teoremas e 1 problema) provas novas, contra as quais
registrei meu protesto (...); e, finalmente, são dadas 6 provas novas que,
creio, bem podem ser introduzidas como alternativas àquelas de Euclides.
Em tudo isto, e em todos os assuntos previamente discutidos, não consigo ver
sequer uma mínima partícula de razão para abandonar Euclides (CARROLL,
2013, p. 199).

O Programa-Manual de Wilson poderia ser, no máximo, considerado uma adição valiosa à literatura sobre Geometria caso, segundo Minos, restituísse os problemas (que são também teoremas) aos seus devidos lugares e mantivesse a numeração de Euclides, interpolando novas proposições onde fosse possível. Sem isso, não merecia sequer ser considerado.

Abandonam-se todos os livros dos rivais, vai-se o fantasma... Niemand, no plural, silencia-se - "Nada mais temos a dizer" (CARROLL, 2013, p. 200) - depois de suas vãs tentativas de defender os quatorze livros que tencionavam substituir Euclides. E desaparece. A noite escura dá lugar ao alvorecer. Em cena, "Minos com o sono agitado, tendo caído para a frente, sobre a mesa, a testa descansando sobre o tinteiro. Em sua direção entra Euclides na ponta dos pés, seguido pelos fantasmas de Arquimedes, Pitágoras, Aristóteles, Platão etc" (CARROLL, 2013, p. 201), geômetras representantes da geometria eterna e imutável organizada por Euclides em seu livro. Minos, que nunca duvidou de que "os velhos amigos são os melhores" $"$, relata a eles

\footnotetext{
${ }^{46}$ Como já apontado na análise de outros livros, a substituição do axioma de Euclides pelo de Playfair não oferece meios para comprovar que as retas consideradas por Euclides encontrar-se-ão se prolongadas.

${ }^{47}$ Os Elementos, Livros I e II.

${ }^{48}$ A citação "Old friends are best. King James used to call for his old shoes; they were easiest for his feet" (Os velhos amigos são os melhores. O rei James falava assim dos seus velhos sapatos, pois eram os
} 
suas análises e diz a Euclides que, em dias de industrialização, construções e estradas de ferro, alguns de seus rivais modernos estão descontentes com a maquinaria escassa que Euclides lhes põe à disposição: apenas régua não graduada e compasso parecem poucas ferramentas para se construir o estudo da geometria em livros que tentavam abordar situações e problemas modernos.

Passo a passo, item a item, livro a livro, Minos relata suas batalhas, mostrando as falhas de cada autor, umas mais graves, outras nem tanto. Quando o dia está para raiar - hora em que "todos os fantasmas respeitáveis devem ir para casa" (CARROLL, 2013, p. 213) -, Carroll mostra-se um pouco mais maleável, ao assumir, num pronunciamento de Euclides:

Deixem-me com a esperança de que os convenci da importância, se não da
necessidade, de manter minha ordem, minha numeração e o meu método de
tratamento de retas, ângulos, ângulos retos e (mais especificamente)
paralelas. Isso se mantendo intocável eu observarei com grande
contentamento outras mudanças serem feitas: minhas provas serem
condensadas e aperfeiçoadas, provas alternativas serem acrescentadas às
minhas e novos problemas e teoremas serem interpolados.
No que diz respeito a esses assuntos, meu manual pode ser aperfeiçoado
ilimitadamente (CARROLL, 2013, p. 213).

Esta afirmação justifica algumas das publicações de Carroll, já citadas neste texto, nas quais ele fazia pequenas modificações na obra de Euclides. Não significa, então, que algumas alterações não pudessem ser feitas n'Os Elementos, mas que o tratamento das paralelas e a numeração - os dois pontos mais defendidos por Carroll ao longo de todo o livro - deveriam ser mantidos tal qual elaborados por Euclides. Quando o combate (e o sonho que a possibilitou) acaba, "Minos acorda com um sobressalto e encaminha-se para a cama" (CARROLL, 2013, p. 213). Exausto, ele pretende dormir. Seu criador, por sua vez, tinha ainda mais trabalho: à peça seguem-se quatro apêndices, sendo dois extratos de artigos sobre geometria elementar que Carroll cita para reforçar seu ponto de vista sobre o uso do livro de Euclides. Tanto o primeiro, de autoria de Todhunter, publicado no livro O Conflito de Estudos e Outros Ensaios Ligados à Educação, quanto o segundo, de autoria de De Morgan, publicado no Athenœum de 18 de julho de 1868, merecem análises detalhadas - no entanto, assim como Minos, nós e nossos leitores já tivemos boa dose de análises...

mais cômodos para os seus pés) é atribuída a John Selden (1584-1654), jurista e político inglês de grande influência que ajudou na elaboração da constituição inglesa. A primeira parte dessa citação é a epígrafe do Ato IV. 


\section{$5 \%$}

Em 18 de dezembro de 1877, Carroll escreve ao seu editor sobre Euclides e Seus Rivais Modernos (cuja primeira edição seria publicada em 1879), comentando sua demora em acabar o livro: “[ele] não estará pronto, receio, até próximo da Páscoa. Ainda não estou nem um pouquinho satisfeito com ele: o assunto é muito complicado e é preciso pensar muito" (CARROLL, 2007, p. 141). Todo o trabalho, tempo e pensamentos empregados na sua concepção, parecem ter valido a pena a julgar pela excelente crítica ao livro publicada em abril de 1879:

Euclides e Seus Rivais Modernos de Charles L. Dodgson, M.A, Estudante Sênior e Professor de Matemática da Christ Church, Oxford, é um notável exemplo de um argumento sério apresentado em estilo divertido, concebido para provar que, para a geometria elementar, um Euclides revisto é melhor do que qualquer substituto moderno proposto. A forma é dramática: Minos e Rhadamanthus, com a ocasional ajuda do próprio Euclides e Niemand, colocam à prova doze (ou, em alguns aspectos, quase vinte) inimigos euclidianos, de modo bem divertido, com engraçados e conclusivos embaraços de todos os tipos... Este é o mais elaborado trabalho matemático de Dodgson e, ao mesmo tempo, um marco para a literatura ${ }^{49}$.

Um livro, como qualquer forma simbólica, abre-se a infinitas interpretações e (re)leituras. Nosso trabalho com o texto Euclides e Seus Rivais Modernos nos aproximou de seu autor, ainda que numa aproximação fugidia como toda aproximação permitida pela leitura, que sempre se renova e se refaz. Diga-se, entretanto, que, a partir desse nosso esforço de examinar hermeneuticamente o livro, passamos a receber amiúde a visita do fantasma de Carroll. Numa dessas visitas perguntamos a ele suas impressões sobre seu livro hoje, visto que, com o passar do tempo, Os Elementos foi mesmo abandonado como livro-texto. Ele teatralmente voltou-se para a porta e apontou para o fantasma de Calvino que entrava em cena e assumia a resposta:

Para que se escreve um romance? Para quem se escreve uma poesia? Para pessoas que leram determinados outros romances, determinadas outras poesias. Um livro é escrito para que possa ser posto ao lado de outros livros, para que entre numa prateleira hipotética e, ao entrar nela, de alguma forma a modifique, expulse dali outros volumes ou os faça retroceder para a segunda fileira, reclame que se coloquem na primeira fileira outros livros (CALVINO, 2009, p. 190).

\footnotetext{
${ }^{49}$ Esta crítica aparece na forma de nota de rodapé, inserida por Morton N. Cohen e Anita Gandolfo no livro sobre as cartas de Carroll e seu editor, à página 141.
} 


\section{Referências}

CALVINO, I. Assunto Encerrado: Discursos Sobre Literatura e Sociedade. Tradução de Roberta Barni. São Paulo: Companhia das Letras, 2009.

CARROLL, L. Alice: Edição Comentada. Rio de Janeiro: Jorge Zahar, 2002a.

CARROLL, L. Matemática Demente. Barcelona: Tusquets Editores, 2002b.

CARROLL, L. Cartas. In: COHEN, M. N; GANDOLFO, A. (Org.). Lewis Carroll and the House of Macmillan.Nova York: Cambridge University Press, 2007.

CARROLL, L. Euclides e Seus Rivais Modernos. Tradução de Rafael Montoito. Bauru: Universidade Estadual Paulista, 2013 (obra no prelo).

CARROLL, L. The Complete Stories and Poems of Lewis Carroll. New Lanark: Geddes \& Grosset, 2005.

COHEN, M. N. Lewis Carroll - uma Biografia. São Paulo: Record, 1998.

CHASTENET, J. A Vida Quotidiana em Inglaterra no Começo da Era Vitoriana (1837 - 1851). Tradução de Elisa Lopes Ribeiro. Lisboa: Livros do Brasil, [s/d].

EUCLIDES. Elementos de Euclides dos Seis Primeiros Livros, do Undécimo e Duodécimo da Versão Latina de Frederico Commandino, Addicionados e Ilustrados por Roberto Simson. Coimbra: Imprensa da Universidade, 1855.

EUCLIDES. Os Elementos. Tradução de Irineu Bicudo. São Paulo: UNESP, 2009.

FOULKES, R. Lewis Carroll and the Victorian Stage: Theatricals in a Quiet Life. Hampshire: Ashgate, 2005.

GATTEGNO, J. L’Univers de Lewis Carroll. Paris: José Corti, 1990.

GENETTE, G. Paratextos Editoriais. Tradução de Álvaro Faleiros. Cotia: Ateliê Editorial, 2009.

HEATH, T. Thirteen Books of Euclid's Elements. Volume 1. New York: Dover, 1956.

LEVI, B. Lendo Euclides: a Matemática e a Geometria Sob um Olhar Renovador. Rio de Janeiro: Civilização Brasileira, 2008.

MARRET, S. Lacan Sobre Lewis Carroll. In: MILLER, J. A. (Org.). Ornicar: de Jaques Lacan a Lewis Carroll. Rio de Janeiro: Jorge Zahar, 2003.

THOMPSON, J. B. Ideologia e Cultura Moderna: Teoria social crítica na era dos meios de comunicação de massa. Petrópolis: Vozes, 1995.

WILSON, R. Lewis Carroll en el País de los Números: Su Fantástica Vida Matemática. Madri: Turner, 2009. 